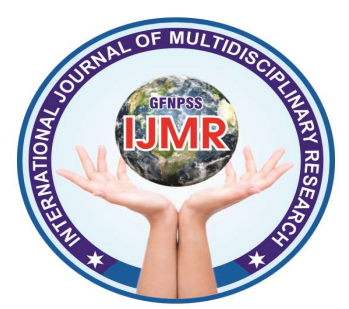

\title{
A STUDY TO ASSESS THE EFFECTIVENESS OF STRUCTURED TEACHING \\ PROGRAMME ON KNOWLEDGE REGARDING USE OF RESTRAINTS ON \\ CHILDREN OF PEDIATRIC WARD AMONG STAFF NURSES
}

\author{
Mrs. Pratibha, M.Sc. Nursing ( Child Health Nursing) \\ Jaipur Hospital College of Nursing, Jaipur
}

Corresponding Email: pratibhagait@gmail.com

\begin{abstract}
Background of the Study: Restraint is often perceived as necessary to ensure that medical procedures are carried out safely. The limited research into nurses' perceptions of restraint practices with hospitalized children hinders understanding the extent of the problem. Restraint should only be used as a last resort and in all situations, nurses should assess the need to use restraint and explore any alternatives in order to gain the child's cooperation.
\end{abstract}

Methodology : An evaluatory approach with pre-experimental one group pre- test post-test design was used for this study. The study was carried out in Soni Hospital, JLN Marg, Jaipur and Manipal Hospital, Vidhyadhar Nagar, Jaipur. The sample comprised of 60 staff nurses The data was analysed using descriptive and inferential statistics

Results : The present study finding showed a highly significant difference between mean pre-test $(\mathrm{X} 1=15.6)$ and post -test $(\mathrm{X} 2=22.67)$ knowledge scores. The mean percentage knowledge score of pre -test was score of Introduction and Definition 38.67\%, questions related to Purpose, Principles \& Types of Restraints 51.19\%, questions related Complication and Management 55\%, whereas the mean percentage knowledge score of post- tests was maximum in the Complication and Management $80.76 \%$, questions related Introduction and Definition 79.33\%, question related to Purpose, Principles \& Types of Restraints $73.33 \%$.

Interpretation and conclusion: The study had shown that majority of the staff nurses had inadequate knowledge on use of restraint.

Keywords: Effectiveness, Structured teaching programme (STP), Attitude, Staff Nurses, Restraints, Children.

\begin{tabular}{ccc}
\hline Received & Accepted & Available online \\
\hline $01 / 09 / 2021$ & $20 / 09 / 2021$ & $02 / 10 / 2021$ \\
\hline
\end{tabular}




\section{INTRODUCTION}

Restraints are devices used for partially or completely immobilizing infants for various medical and nursing procedures. The common type of restraints includes Jacket restraint, Mummy restraint, Extremity restraint, abdominal restraint, elbow restraint and Crib with Dome. ${ }^{1}$

The main purpose of restraints includes immobilizing the infant, to quieten the child, to examine the specific body parts and to perform medical and nursing procedures. $^{2}$

A simple pediatric restraint for restraining movement makes procedure with pediatric patient much easier. The method uses a standard readily available bed sheet, which is easy to learn, can be modified for use on various body areas, and makes short procedures possible with minimal nursing assistance. $^{3}$

Whenever nurses have to make decisions regarding the use of restraints, they may find themselves in the midst of conflicts between their professional obligation to care for a patient's well-being and concerns about a patient's right to make an informed choice. ${ }^{4}$

Nurses are most intimately involved in the decision to restrain and in its implementation. However, few studies are found which explore nurses' attitudes towards, or issues relating to the practice of, physical restraints in different clinical settings. ${ }^{5}$

Restraints have the potential to produce serious outcomes, including physical or psychological harm, loss of dignity, violation of patient's rights and possibility death. Health care providers need to identify opportunities to decrease the risks associated with the use of restraints through preventive strategies, innovative alternatives and process improvements to help focus on the pediatric patient's over. ${ }^{6}$ Nurses need to assess whether or not restraints are needed. The nurses need to take into account the child's development, mental status, potential threat to others or self and safety. In some health care institutions, the decision to apply a restraint is a nursing decision, whereas in others a physician's order is required before or within 1 to 2 hours of application. Parental consent may be required for reasons other than procedures. $^{7}$

Nurses play an important role in the practice of using physical restraints in children. Until more research is available, nurses need to carefully assess the children 


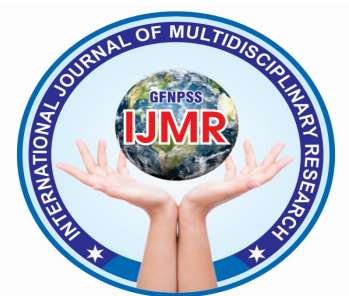

in their care and apply the nursing process out by using Spearman Brown Prophecy in the use of restraints. So the investigators felt the need to assess knowledge on regarding restraining and provide health education in the form of structured teaching programme .

\section{METHODOLOGY}

An evaluatory approach with preexperimental one group pre- test post-test design was used ; with the main objective to assess the pre-existing level of knowledge regarding restraints, to find out the effectiveness of structured teaching programme on knowledge regarding, to find out the association between pre-test knowledge regarding restraints among pediatric nurses with their selected socio demographic variables. The researcher prepared a structured knowledge questionnaire on use of restraints with 30 questions knowledge and a structured teaching programme was developed based on pre-test knowledge score. The preparation of the questionnaire and structure teaching programme was carried out after review of literature, discussion with guide and nine subject experts. A pilot study was conducted on 6 staff nurses at Jaipur. The validity of the tool and structure teaching programme was carried formula. The main study was conducted with 60 subjects. The data was analysed with descriptive and inferential statistics (paired t-test and Chi Square test).

\section{RESULT}

Table 1: Frequency and percentage distribution of socio demographic variables

$\mathbf{N}=\mathbf{6 0}$

\begin{tabular}{|c|c|c|c|c|}
\hline Sr. & \multicolumn{2}{|c|}{ Demographic information } & \multirow{2}{*}{$\begin{array}{c}\begin{array}{c}\text { No. of } \\
\text { parent } \\
\text { s }\end{array} \\
18\end{array}$} & \multirow{2}{*}{$\begin{array}{l}\% \text { of } \\
\text { respondents } \\
30.00 \%\end{array}$} \\
\hline \multirow[t]{4}{*}{1} & \multirow[t]{4}{*}{ Age } & $21-25$ years & & \\
\hline & & $26-30$ years & 19 & $31.67 \%$ \\
\hline & & $31-35$ years & 14 & $23.33 \%$ \\
\hline & & Above 35 & 9 & $15.00 \%$ \\
\hline \multirow[t]{2}{*}{2} & \multirow[t]{2}{*}{ Sex } & Male & 27 & $55.00 \%$ \\
\hline & & Female & 33 & $45.00 \%$ \\
\hline \multirow[t]{4}{*}{3} & \multirow[t]{4}{*}{ Religion } & Hindu & 27 & $45 \%$ \\
\hline & & Muslim & 18 & $30 \%$ \\
\hline & & Christian & 10 & $17 \%$ \\
\hline & & Others & 5 & $8 \%$ \\
\hline \multirow[t]{4}{*}{4} & \multirow[t]{4}{*}{ Education } & GNM & 27 & $45.00 \%$ \\
\hline & & B.Sc. Nursing & 13 & $21.67 \%$ \\
\hline & & P. B.Sc. Nursing & 17 & $28.33 \%$ \\
\hline & & M.Sc. Nursing & 3 & $5.00 \%$ \\
\hline \multirow[t]{4}{*}{5} & \multirow{4}{*}{$\begin{array}{c}\text { Experience } \\
\text { of } \\
\text { staff }\end{array}$} & $0-4$ years & 22 & $36.67 \%$ \\
\hline & & 5-8 years & 19 & $31.66 \%$ \\
\hline & & 9-12 years & 12 & $20.00 \%$ \\
\hline & & Above 12 years & 7 & $11.67 \%$ \\
\hline \multirow[b]{2}{*}{6} & \multirow{2}{*}{ 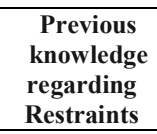 } & Yes & 13 & $21.67 \%$ \\
\hline & & No & 47 & $78.33 \%$ \\
\hline
\end{tabular}

GFNPSS-International Journal of Multidisciplinary Research, Volume 2, Issue 9, September 2021

DOI: 10.46376/IJMR/2.9.2021, P a g e 791| 45 


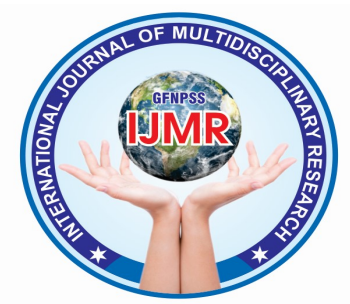

years age group, $23.33 \%$ (14) belongs to

Table No.2: Distribution of level of knowledge on use of restraint on children among staff nurses in pre and post-tests.

\begin{tabular}{|l|l|l|l|l|l|l|}
\hline S. & $\begin{array}{l}\text { Level of } \\
\text { No }\end{array}$ & $\begin{array}{l}\text { Knowled } \\
\text { ge }\end{array}$ & Score & \multicolumn{2}{|l|}{ Pre-Test } & \multicolumn{2}{l|}{ Post-Test } \\
\cline { 3 - 7 } & & $\begin{array}{l}\text { Freque } \\
\text { ncy }\end{array}$ & $\begin{array}{l}\text { Perce } \\
\text { ntag } \\
\text { e }\end{array}$ & $\begin{array}{l}\text { Freq } \\
\text { uenc } \\
\text { y }\end{array}$ & $\begin{array}{l}\text { Perce } \\
\text { ntage }\end{array}$ \\
\hline 1 & Poor & $<40$ & 20 & 33.33 & 2 & 3.33 \\
\hline 2 & Average & $\begin{array}{l}41- \\
60\end{array}$ & 22 & 36.67 & 4 & 6.67 \\
\hline 3 & Good & $\begin{array}{l}61- \\
75\end{array}$ & 12 & 20 & 12 & 20 \\
\hline 4 & $\begin{array}{l}\text { Very } \\
\text { Good }\end{array}$ & $>75$ & 6 & 10 & 42 & 70 \\
\hline \multicolumn{2}{|l|}{ Total } & & 60 & 100 & 60 & 100 \\
\hline
\end{tabular}

Table No.3 : Significance difference between pre-test and post-test knowledge scores

\begin{tabular}{|c|c|c|c|c|c|}
\hline Score & $\begin{array}{l}\text { Mea } \\
\mathrm{n} \\
\overline{\boldsymbol{x}}\end{array}$ & S.D. & $\begin{array}{c}\text { Standard } \\
\text { Error }\end{array}$ & $\begin{array}{l}\text { Mean } \\
\text { Difference }\end{array}$ & $\begin{array}{l}\text { Calcula } \\
\text { ted 't' } \\
\text { Value }\end{array}$ \\
\hline $\begin{array}{l}\text { Pre- } \\
\text { test }\end{array}$ & 15.6 & 5.08 & \multirow[t]{2}{*}{0.84} & \multirow[t]{2}{*}{7.07} & \multirow[t]{2}{*}{8.42} \\
\hline $\begin{array}{l}\text { Post- } \\
\text { test }\end{array}$ & 22.67 & 4.11 & & & \\
\hline
\end{tabular}

Regarding age group maximum, of sample belong to $31.67 \%$ (19) age group $26-30$ followed by $30 \%$ (18) belongs to $21-25$
31-35 years age group, $15.00 \%$ (9) belongs to the age groups of above 35 years. Regarding gender majority of subjects $55 \%$ (33) was female and only $45 \%$ (27) was males. As regarding religion majority of sample was Hindu 45\% (27) followed by $30 \%$ (18) Muslim religion, 17\% (10) Christian religion and only $8 \%$ (5) sample belongs to the other religion. Regarding education qualification majority of staff nurses had completed General Nursing and Midwifery 45\% (27). Regarding total work experience majority of staff nurses $36.67 \%$ (22) have experience $0-4$ years.(table 1)

Regarding previous knowledge related to use of restraints on children majority of staff $78.33 \%$ (47) have no knowledge regarding use of restating.( table 2)

The knowledge scores of staff nurses nurse regarding use of restraints on children among staff nurses has revealed that, posttest knowledge score was found higher $22.67 \%$ and SD of 4.11 when compared with pre-test mean knowledge score which was $15.6 \%$ with SD of 5.08 the mean effectiveness score was $7.07 \%$ the results of the study depicts that the structure teaching programme was very effective in improving the knowledge of staff nurse 


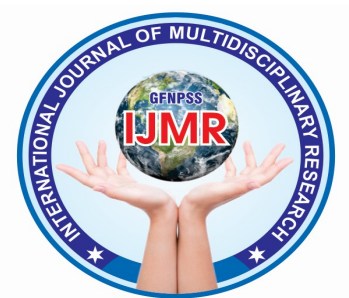

regarding use of restraints on children among staff nurses. ( table 3 )

As per the finding of the present study

Chi-Square test was carried out to show the association between pre-test score level of staff nurses regarding use of restraints on children with their selected demographic variables such as age, gender, religion, professional qualification, total work experience, previous knowledge, there is no significant association at the level of $\mathrm{P}<0.0001$ with all demographic variables.

\section{DISCUSSION}

Most of the staff nurses had inadequate knowledge of staff nurses regarding the use of restraints and some staff nurses have knowledge about the use of restraints on children because of some previous experience of use of restraints on children. The findings of the study were similar with the findings of Mehrok $\mathrm{S}$ which revealed that about two-thirds of nurses had modest level of knowledge of restraint use. ${ }^{7}$

Our study shows that there is no significant relationship between pre-test score level of staff nurses and their selected demographic variables such as age, gender, religion, professional qualification, total work experience, previous knowledge and this finding is supported by a study conducted on to find out a significant relationship between socio demographic variables (age, gender, religion, professional qualification, total work experience etc.) And knowledge level of staff nurses in china. Sample consisted of 200 adolescents, age group of $13-18$ years. He used survey method to collect the data. Significant no association of knowledge with their demographic variable at $(\mathrm{P}<0.05)$ noted. ${ }^{8}$

Structured teaching programme is found to be an effective educati0nal method for improving the knowledge of staff regarding restraints. These findings were similar to the other studies [9],[11] which showed that teaching programme is an effective educative method for improving the knowledge of staff nurses regarding restraints. ${ }^{1}$

\section{CONCLUSION:}

Conclusions drawn from present study were structured teaching on restrain among staff nurse through lesson plan was an effective method. So there is a need to educate the staff nurse regarding use of restraints in paediatric ward. Concern health administrator should take initiative in adopting policies or plan providing 


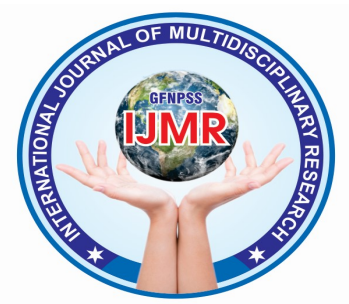

continues education to health care personal regarding policy and use of restrains.

\section{REFERENCES}

1. Mahesh M. Rebinal. Restraints and Its Use for Children. Asian J. Nur. Edu. and Research 4(4): Oct.- Dec., 2014; Page 472-480. 2. Vivian Rose Ramsden, "Nursing principles and practice manual", Edited by Sivagami Natesan and Susan Jacob, edition - 1st, 1999, page no- 388391.

2. Raskin BI, "A simple pediatric restraint", Cutis $2000 \mathrm{NOV}$; 66(5): $335-6$

3. Eskandari F, Abdullah KL, Zainal NZ, Wong LP. Use of physical restraint: Nurses' knowledge, attitude, intention and practice and influencing factors. $\mathrm{J}$ Clin Nurs. 2017;26:4479-88.

[PubMed]

[Google Scholar]

4. Azab SM, Azab SMS, Negm LA. Use of physical restraint in intensive care units (ICUs) at ain shams university hospitals. J Am Sci. 2013;9:230-40. Avaliable frorm: http://wwwjofamericanscienceorg $\mathrm{http} / /$ wwwjofamericanscienceorg . [Google Scholar]
5. Gunawardena R, Smithard DG. The Attitudes Towards the Use of Restraint and Restrictive Intervention Amongst Healthcare Staff on Acute Medical and Frailty Wards-A Brief Literature Review. Geriatrics (Basel). 2019 Sep 4;4(3):50. doi: 10.3390/geriatrics4030050. PMID: 31487923 ; PMCID: PMC6787583.

6. DONNA L WONG, "Nursing care of infants and children: Edition-6th, page no- 1246-1248.

7. Mehrok S, Belsiyal CX, Kamboj P, Mery A. The use of physical restraints- knowledge and attitude of nurses of a tertiary care institute, Uttarakhand, India. J Educ Health Promot. 2020 Mar 31;9:77. doi: 10.4103/jehp.jehp_451_19. PMID: 32490012; PMCID: PMC7255578.

8. Huang HT, Chuang YH, Chiang KF. "Nurses' physical restraint knowledge, attitudes, and practices: the effectiveness of an in-service education program." Department of Nursing, Chung Hwa University of Medical Technology, Taipei, Taiwan, J Nurs Res. 2011 Dec;17(4):241-8. 